\title{
Determinants of the Release of Imprest to Units within Public Institutions of Developing Countries: Evidence from University of Calabar, Nigeria
}

\author{
William Smart Inyang \\ Department of Accounting, University of Calabar, Nigeria
}

Copyright $(2016$ by authors, all rights reserved. Authors agree that this article remains permanently open access under the terms of the Creative Commons Attribution License 4.0 International License

\begin{abstract}
It is not clear why imprest funds which are solely used for the implementation of the overhead cost budget are not effectively released to spending units found within public institutions of developing countries. The current study was therefore, carried out to discover the reasons why academic departments of a public institution like Nigeria's university of calabar do not receive their monthly imprests every 9 out of 12 times per annum (i.e. imprest funds are not released 75 percent of the time!). Primary data were collected using a 5-point likert scale questionnaire while six hypotheses were formulated and tested for the study using multiple regressions. The study revealed that delay in the release of imprest funds to spending units of public institutions was due to management's lack of confidence in the spending units' overhead cost budgets, cumbersomeness of procedures for releasing imprest, late retirement of imprest and personal considerations while late budget approval and side-lining of units' finance officers had negligible or no association with the delay in the release of imprest. The study therefore, recommended that public institutions' managements should demonstrate commensurate confidence in their units' overhead cost budgets, adopt time-saving imprest procedures and place appropriate sanctions against late retirement of imprest and personal considerations.
\end{abstract}

Keywords Release of Imprest Funds, Confidence in the Overhead Cost Budget, Budget Approval Date, Imprest Payment Procedures, Imprest Retirement Period, Side-lining of Finance Officers and Personal Considerations

\section{Introduction}

\subsection{Background of the Study}

Recent studies have focused on the funding of governmental organizations. Delays in the release of funds meant for government businesses have been recently reported in several quarters $[13,18,5,1,9$, and 20]. Uzochukwu etal [20] further asserted that all areas of supply and service delivery mostly at the grass root are adversely affected by inadequate funding. Asomba [4] reported that the head of department of education management of Lagos State University lamented that one of the factors that hampers effective teaching, learning and research is the difficulty of the Ivory Towers in getting monthly imprest. Funds delayed therefore, means service delayed. Imprest is another public fund that is not adequately released to public institutions in Nigeria and other developing countries despite its widespread usage and importance. According to Danka [7] imprest just like other government funds, is extensively used by organizations of all sizes. This type of fund is a fixed amount of money released to government departments on monthly basis to service recurrent expenses [2]. Other types of imprests like special imprest and additional imprest are also released to government departments [10].

The administrative effectiveness of spending units in public institutions is generally the reason why it is an obligation for the various managements of public institutions to release imprest to their departments on a regular basis. Within the 10 faculties and 3 institutes of University of Calabar, there are presently 68 departments whose recurrent teaching and learning activities are serviced using imprest funds. All the 68 academic departments are statutory required to use imprest to service their day-to-day running and administrative expenses.

Imprests should therefore, not be released arbitrary since there are regulations and guidelines for releasing imprests to all users of imprest funds and where such procedures are not followed, problems will consequently arise. Financial regulations in Nigeria, require that imprest be released every month for 12 calendar months of the year based on an imprest warrant of a fixed amount which management issues at the beginning of every year.

Study carried out by Usabor [19] showed that school imprest predicts principals' administrative effectiveness in 
public secondary schools. Ragusa [16] reported that what is spent is what is replenished and that, documentation of the amount requested is mandatory. Cantoria [6] Danka [7] and Wilkinson [21] claimed that the imprest system makes the inexpensive items of business to be procured without any problem and without the imprest account, it will take a longer time for very important goods and services required by an organization to be procured.

Despite the reported delays in the release of imprest and other government funds and the widespread use of the imprest system, no study has been carried out to explain why imprest funds are not released to departments in public institutions of developing countries on their due dates. The purpose of the current study is therefore, to identify factors that have significantly contributed to the epileptic release of imprest funds to departments in public institutions of developing countries, using Nigeria's University of Calabar as study area. Over 50 percent of all the 92 sampled academic and non-academic staff of University of Calabar reported that academic departments do not receive their monthly imprests 9 times out of 12 times per annum (i.e. imprest is not released 75 percent of the time!). How do policy and environmental factors significantly contribute to the annual low rate of release of imprest funds to units within public institutions of Nigeria and other developing countries? This is the question the current study will attempt to answer.

\subsection{Statement of Problem}

The successful implementation of the overhead cost budgets of departments found within public institutions substantially depends on the timely and effective release of approved funds. The amount of imprest fund which is arbitrary fixed by management for the implementation of the overhead cost budgets of all the 68 academic departments (spending units) of university of calabar is $\$ 12,240,000$. $\{\$ 62,132\}(\$ 15,000$ or $\$ 76.14$ monthly imprest $x 12$ months $\mathrm{x} 68$ departments).This is however, grossly less than the approved amount in the overhead cost budgets of all the academic departments. Unfortunately, only 25 percent of this grossly inadequate amount is released annually for recurrent services. Over 50 percent of the 92 academic and non-academic staff of the university, who participated in the survey, revealed that imprest fund was actually released only 3 times per annum to all the academic departments. The implication of this revelation is that only $\$ 3,060,000$ $\{\$ 15,533\}$ is annually released to all the departments (i.e. $\$ 15,000$ monthly imprest x 3 months x 68 departments). What this scenario therefore, suggests is that these departments are denied of their legitimate imprests for 9 months bringing the total imprest funds not received per annum to $\$ 9,180,000\{\$ 46,599\}$. According to the affected academic departments, this sad situation has been going on year in year out and this has affected their administrative effectiveness. The situation is so bad that basic things like electricity, water, stationery, office equipment maintenance, toiletries, air fresheners, timely delivery of office correspondences and students' sessional and degree results, postal services, internet services, newspapers, magazines and first aid materials cannot be adequately and regularly procured. How do policy and environmental factors contribute to delays in the release of imprest funds to spending units in public institutions of Nigeria and other developing countries?

\subsection{Objectives of the Study}

The main objective of this study is to examine how policy and environmental factors contribute to the low percentage rate of release of imprests to units in public institutions of Nigeria and other development countries using Nigeria's university of calabar as study area. The specific objectives to be achieved in this study are as follows:

- To examine whether the lack of management's confidence in the overhead cost budget has any impact on the release of monthly imprest to academic departments of university of calabar.

- To verify whether the late approval of overhead cost budget has any impact on the release of monthly imprest to academic departments of university of calabar.

- To identify whether the release of monthly imprest to academic departments of university of calabar is based on the imprest warrants being released at the beginning of each year.

- To evaluate the impact of cumbersome procedures on the release of monthly imprest to academic departments of university of calabar.

- To assess the impact of late retirement of imprest on the release of monthly imprest to academic departments of university of calabar.

- To verify whether the deliberate sidelining of departmental finance officers has any impact on the release of monthly of imprest to academic departments of university of calabar.

- To verify whether personal considerations have any impact on the release of monthly imprest to academic departments of university of calabar.

- To make recommendations based on the findings of the study.

\subsection{Research Questions}

The following research questions have been formulated to guide the current study:

- To what extent has the lack of management's confidence on the overhead cost budget impacted on the release of imprest to academic departments of university of calabar?

- How does the late approval of overhead cost budget affect the release of monthly imprest to academic departments of university of calabar?

- Is the release of monthly imprest to academic departments of university of calabar based on imprest 
warrants being released at the beginning of each year?

- How do cumbersome procedures influence the release of imprests to academic departments of university of calabar?

- How does late retirement of imprest affect the release of monthly imprest to academic departments of university of calabar?

- What impact does the deliberate sidelining of departmental finance officers make on the release of monthly imprest to academic departments of university of calabar?

- How do personal considerations affect the release of monthly imprest to academic departments of university of calabar?

\subsection{Research Hypotheses}

- There is no significant relationship between management's confidence in the overhead cost budgets and release of imprests to academic departments of university of calabar.

- There is no significant relationship between date of approval of overhead cost budgets and release of imprests to academic departments of university of calabar.

- There is no significant relationship between imprest payment procedures and release of imprests to academic departments of university of calabar.

- There is no significant relationship between the time taken to retire imprest and release of imprests to academic departments of university of calabar.

- There is no significant relationship between the side-lining of departmental finance officers and release of imprests to academic departments of university of calabar.

- $\quad$ There is no significant relationship between personal considerations and release of imprests to academic departments of university of calabar.

\subsection{Scope of the Study}

This study on the determinants of the release of imprest funds to spending units will be restricted to only public institutions in Nigeria and some developing countries. Government imprest funds are used to render recurrent services provided for in the approved overhead cost budget. Therefore, only the recurrent services in the approved overhead cost budget of public institutions will be discussed. This is the reason why the release of monthly imprest is oftentimes regarded as a function of the annually approved overhead cost budget. The determinants of the release of the imprest funds to spending units in private institutions will not be covered in the current study.

\subsection{Justification of the Study}

Generally speaking, poor funding with its attendant consequences rears its ugly head whenever, developing countries' institutions embark on their recurrent and non-recurrent activities. In Tanzania, delay in the release of funds was ranked No. 4 by 40 respondents in a Survey as being one of the 21 major causes of disruptions in the construction of public institutions' projects [24]. In Kenya, it took 15 months for project funds to be received after disbursement by donor agencies [11]. Public institutions' budgets and project implementation failed in India, Ghana, Uganda and Nigeria due to undue delay in the release of funds $[17,18,15,3,1,20]$. Not releasing imprest regularly to public institutions including the university of calabar, has also resulted in incessant strikes and students' unrest arising from salary delays, lack of portable water, poor sanitary conditions in offices and lecture rooms, poor ventilation in offices and lecture rooms, disruption in electricity supply and lack of first aid facilities just to mention a few. All these have adverse effects on teaching, learning and research and incessant delays in the completion of undergraduate and post-graduate programmes. Asomba [4] asserted that the inability of the Ivory Towers in Nigeria to receive their monthly imprest is one of the factors that have hampered effective teaching, learning and research. In virtually all educational institutions in Nigeria, lack of funds is a general problem [22]. This is further supported by Okafor [23] who reported that poor funding is the major cause of the frequent strike action by Academic Staff Union of Universities (ASUU), lack of teaching and learning facilities, fall in staff morale, poor attitude to work and inability to achieve program objectives.

Poor recurrent funding has also led to poor maintenance culture and this has robbed Nigerian universities of a lot of resources. Cheap and regular maintenance are ignored until these facilities are completely destroyed [25]. Oyekanmi [25] further observed that basic things like water, electricity, transportation and health facilities are grossly insufficient. Experience has shown that most academic staff seldom go for local and international conferences due to lack of funds. Oftentimes those conferences are funded from their own personal resources and such personal funds take more than a year to recover or are never recovered at all. This study therefore, seeks to discover those undisclosed factors that are responsible for the perennial low rate of release of monthly imprest funds to units in public institutions of developing countries. The current research forms the basis for future studies and provides a contribution to knowledge.

\subsection{Significance of the Study}

The study will benefit the society by offering solutions to recurrent funding problems which oftentimes lead to trade union disputes, students' unrests and public demonstrations. Such demonstrations are often taken to the streets to destroy lives and public property and disrupt the public peace. Such unfortunate incidences will not occur again as a result of the study. Developing countries where these universities are sited will experience relative peace and will spend less on 
settling academic staff and students disputes and innocent students will no longer be forced to pay for school property they did not destroy. Universities will have good rapport with their students and academic staff. These public institutions will be able to effectively manage the procedures for releasing imprest funds to their respective units and such institutions will also secure government and public confidence. Administrators of universities and other public institutions of developing countries will become knowledgeable in the management of their imprest systems. Academic heads of departments in these universities and heads of other public institutions who collect their imprests regularly will be able to render their recurrent services effectively. Academic staff and students will experience a conducive teaching, learning and research environment and their relationships will become cordial and mutually beneficial. Finally, the study will enable researchers to discover critical areas in the imprest request and reimbursement processes that many researchers were unable to explore.

\subsection{Conceptual Framework}

Imprest funds are used to pay for items included in the overhead cost budget and these items are: local travels and transport, telephone services, stationery items, entertainment and hospitality, maintenance of vehicles, maintenance of buildings and other capital assets, maintenance of office furniture and equipment, and staff training and development. In Nigeria and other developing countries, imprest funds are used to render recurrent services which facilitate the release of other funds such as personnel emolument and capital project funds. In fact, if imprest funds are not promptly released, payroll staff, budget staff and other staff will not be able to perform their routine duties effectively and all recurrent activities that usually aid the speedy implementation of capital projects cannot be effectively carried out. Universities and other public institutions in Nigeria have the same overhead cost structures, imprest system and their imprest duties are guided by the same financial regulations.

The conceptual framework of this study was based on the agency theory, time value of money concept and contingency theory. Consequently, seven research variables were generated for the conceptual framework. These variables are: release of imprest to academic departments (dependent variable), Management's confidence in the overhead cost budget, date of approval of overhead cost budget, imprest payment procedures, period of imprest retirement, sidelining of departmental finance officers and personal considerations (independent variables).

The interrelationships between the aforementioned variables are depicted in the schematic diagram (figure 1) below:

\section{Independent Variables}

1. Management's confidence in the overhead cost budget

2. Date of approval of overhead cost budget

3. Imprest payment procedures

4. Period of imprest retirement

5. Sidelining of departmental finance officers

6. Personal considerations

Dependent Variable

Release of imprest to academic departments

Figure 1. Conceptual Framework 
The current study is guided by the fact that imprest can only be effectively released to academic departments when Management has confidence in the annually approved overhead cost budget of each academic department. Early approval of overhead cost budget estimates can also facilitate the timely release of imprest. How can delay in the release of imprest be curbed when imprest payment procedures are cumbersome and imprest already expended is not promptly retired or accounted for? Furthermore, the release of imprest to a large extent also depends on the regular and consistent involvement of departmental finance officers. Oftentimes, finance officers are sidelined when personal interests are being pursued. Therefore, the interrelationships which exist between these conceptual variables will be used to conduct the current study.

\subsection{Operational Definition of Variables}

- Release of imprest to academic departments: The number of times the majority of the respondents say imprest is released to academic departments per annum. It is also defined as the composite response scores of each respondent's extent of agreement that imprest is released to academic departments.

- Management's confidence in the overhead cost budget: The composite response scores of each respondent's extent of agreement that universities' managements lack confidence in the overhead cost budgets of academic departments.

- Date of approval of overhead cost budget: This is the composite response scores of each respondent's extent of agreement that early approval is given to the overhead cost budgets of academic departments.

- Imprest payment procedures: This is the composite response score of each respondent's extent of agreement that the procedures for releasing imprest to academic departments are cumbersome.

- Period of imprest retirement: This is the composite response score of each respondent's extent of agreement that academic departments usually delay the retirement of the imprest given to them.

- Sidelining of departmental finance officers: This is the composite response score of each respondent's extent of agreement that academic heads of departments usually usurp the functions of their finance officers.

- Personal considerations: This is the composite response score of each respondent's extent of agreement that the release of imprest to academic departments is based on personal considerations.

\section{Literature Review}

\subsection{Theories Justifying the Study}

2.1.1. Agency Theory
This theory refers to the relationship between the principal and his agent. The agent performs some tasks which are given to him by his principal. This theory is related to the current study because a relationship exists between the management of public institutions (Principal) and the Heads of units in public institutions (Agent). The level of imprest to be disbursed is determined by the public institutions' management who releases same to the various heads of units. The heads of units act based on the approved overhead cost budgets and existing financial regulations.

An assumption of this theory is that the public institution's management and heads of units in public institutions are unitary entities. The principal does not have any foundation for trusting his agent because the agent's interest and information are sometimes different from the principal's own. The principal will therefore, take some mitigating measures to ensure that his agent acts according to his preferences or reduce the scope of the differences in information and interest existing between him and his agent.(Walker, 2003, as cited in Keng'ara, [11]). The public institution's management (principal) is expected to have confidence in the overhead cost budget submitted by heads of units in public institutions (agents). It is the responsibility of management to adopt procedures that facilitate the prompt release of imprest. Management is also expected to promptly approve the overhead cost budget and to shun personal considerations and godfather's approach in its dealings with heads of units.

The position of Walker is supported by the Institute of Chartered Accountants of England and Wales, 2005 as cited in Keng'ara, [11] that the agents (heads of units) and principal (the public institution's management) are likely to have separate reasons for acting in a particular manner due to factors relating to monetary benefits, prospects in the labour market and association with stakeholders not connected with the principal. Sometimes, heads of units prepare and submit overhead cost estimates that are not realistic. Agency theory requires that heads of units submit realistic budgets, retire their imprests promptly and shun personal considerations when using imprests allocated or released to them.

\subsubsection{Time Value of Money}

This concept states that receiving a certain amount of cash now is more preferable to receiving the same amount at a certain future date. For example, $\$ 15,000$ (fifteen thousand naira) imprest received today is worth more than $\$ 15,000$ imprest received a week or month later. This is because of the risk associated with consumption preference and investment opportunities. For the effective implementation of each academic department's overhead cost budget, heads of department need to receive funds promptly so that the purchasing power of the imprest funds is not reduced or weakened. Imprest can be received promptly when the confidence of management in the overhead cost budget is high. Early approval of the overhead cost budget, quick processing of payment request, early retirement of imprest already spent non-usurpation of finance officers' duties and 
non-pursuance of personal interest can foster the prompt release of imprest.

\subsubsection{Contingency Theory}

This theory contends that the optimal planning and control systems are determined by several internal and external factors. A particular approach to planning and control that is suitable or effective for one circumstance may not be suitable for other circumstances. Relating this theory to the current study means that planning and controlling the release of imprest to spending units in public institutions should be based on changing circumstances or situational factors other than on fixed and outdated overhead cost budgets. Changing circumstances can make the overhead cost budget to become outdated. When this occurs, the budget should be revised to suit such changing circumstances so that the performances of the various spending units can become more efficient and effective. The contingency theory supports the constant revision of the overhead cost budgets which paves the way for effective release of imprest to public institutions' spending units. The relevance of this theory to the current study is further revealed by its usefulness in improving the level of confidence in the overhead cost budget, facilitating the prompt approval of the overhead cost budget, making the imprest payment procedures faster, ensuring that other people's functions are not being usurped and ensuring that personal considerations do not rear their ugly heads.

\subsection{Review of Related Literatures}

The current study falls within the context of factors that influence the release of funds to public institutions. This is because the release of funds to public institutions is synonymous with the release of funds to spending units within public institutions. Furthermore, these two classes of fund releases are determined by policy and environmental factors and are governed by the same government financial regulations. Public institutions and units found within them are all classified as spending units which government usually releases funds to. Consequently, the review of literature will be conducted under the following themes: budget and warrant approval date, unrealized revenue budgets, level of confidence in the approved budget, fund release procedures, level of adherence to due process, mismanagement of public funds, sanctions and the use of Monitoring and Evaluation (M\&E) and Public Expenditure Tracking System (PETS). In spite of the fact that previous literatures discussed these themes in different circumstances, the current paper will discuss how they influence the release of government capital and recurrent budget implementation funds, public institutions' project implementation fund and donor project implementation fund in Nigeria and other developing countries.

Funds cannot be released to public institutions without their budgets being approved before the commencement of the financial year. When budget approval is delayed, release of funds will be delayed. Government funds cannot be released by the relevant authorities if the appropriation bill is not passed by the national assembly and this oftentimes consumes a lot of time. Section 81 of the constitution of the Federal Republic of Nigeria stipulates that no monies can be taken from the consolidated revenue fund (CRF) for expenditure without the approval of the National Assembly. Obadan [14] discovered that late passages of 2005 and 2006 capital budgets made the proportion of funds released in relation to funds utilized to show a declining performance between 2005 and 2008. Absorption of Fund Brief [1] revealed that delays in the approval of warrant were responsible for the late release of funds to the energy sector. However, an early or a promptly approved budget does not always guarantee the prompt release of funds especially when the revenue budget is not realized.

The inability of MDAs and governments to realize their revenue budgets has led to delay in the release of funds. Obadan [14] attributed the untimely release of appropriated funds to revenue shortfalls. This is further supported by Dankwambo [8] who reported that fund releases by government depend greatly on the realization of the revenue budget. Obadan [14] however, reported that boom in Nigerian national revenue did not prevent delay in the release of funds meant for implementing government capital and recurrent projects i.e. funds were still being delayed in the past even when lack of revenue was not a barrier. This therefore, suggests that budgets could be sidelined by the management of public institutions if it lacks confidence in the budgets.

The management of public institutions have deliberately sidelined the budget even when the Nigerian revenue budget was realized suggesting that confidence in the budget was lacking. This has consequently resulted in the epileptic release of public funds for the implementation of government projects and other recurrent activities. This lack of confidence in the budget is also expressed in the findings of Uzochukwu, Chukwuogo and Onwujekwe [20] who reported that at all three levels of government in Nigeria, budgetary provisions were made but, releases of funds were not. Nzotta [13] in his study on the management of Library in Nigeria showed how confidence in the budget was lacking when he reported that vote allocated was not what was actually released and that approved budget was only on paper and what was released or cash backed was a very small percentage of what was approved. In addition to sidelining the budget, most management of public institutions have failed to look into the time-consuming nature of their fund release procedures.

Cumbersome and complex payment procedures have been found to be responsible for most fund delays in public institutions. Keng'ara [11] in his study of disbursement procedures, discovered that what delayed the receipt of funds meant for donor project execution was the complex methods of disbursements. Furthermore, the donor and government officials most times do not have the same method of procurement and project execution time will be lost as a result. Keng'ara further disclosed that when the receipt of 
funds is delayed, suppliers' payments are delayed, cost of project goes up leading to late completion or outright abandonment of project. Absorption of Fund Brief [1] further disclosed that even though funds released to recipient institutions arrived late, they were still made to pass through intermediary institutions and funds meant for the construction of schools in local government areas were kept in district account for a long time. The cumbersomeness of procedures was also highlighted by Dwivedi [9] who discovered that confirmation of credit, releasing funds and returning confirmation file after getting approval from finance department usually took a long time and these delayed utilization of funds. This was further supported by Basu and sharma [5] who asserted that when spending units delay the submission of utilization certificate, funds will not be promptly released especially when the release of subsequent tranche of the funds depends upon the submission of utilization certificate. Basu and Sharma further asserted that where the State budget is not in line with the work-plan of the sponsoring agency, obtaining approval for budget re-appropriation consumes a lot of time and the release of funds to spending units will be delayed. Finally on cumbersomeness of procedures, procedural and environmental factors disrupted the timely release of funds to execute public projects in Ghana. SEND-Ghana (2013 as cited in Akorli [3]) attributed the delay in the release of project funds to the following: delays in funds transfer, late inspection of projects, bureaucratic contract award procedures, making contractors to offer bribes by intentionally frustrating them and complex and time-consuming procurement procedures. It has therefore, been established that when procedures are complex and cumbersome, regular release of funds will be hampered. Apart from blaming management for sidelining the budget and adopting complex fund release procedures, other studies revealed that recipients of government funds are also to blame for their failure to adhere to due process which has led to fund delays.

The failure by government fund recipients to follow due process has caused funds not to be promptly released to them. Absorption of Fund Brief [1] reported that the release of funds was delayed because the involvement of district technical officers was limited in the agricultural and educational sectors. Furthermore, in Madhubami district in India, late submission of proposals, delayed procurement, arguments over tendering rules, questionable contractors and companies delayed the release of funds for implementation of government projects [18]. Still on non-adherence to due process, Rauf [17] reported that Khyber Pakhtunkhwa (K-P) in India had not seen a dime of the Rs 103.79 it was meant to receive because the fund was not requested for. Fund delays will occur when due process is not adhered to.Non-compliance with laid down procedures has robbed LGAs of clean audit reports (unqualified audit report) and it has also made fund release requirements not to be easily fulfilled by MDAs. Quality DADP Plans [15] revealed that in certain circumstances, release of funds to support Tanzania's agricultural development projects depends on clean audit report being issued to LGAs. Only LGAs with clean audit reports would receive funds on time or else delay will occur and instead of sanctioning the defaulting civil servants, communities will rather bear the brunt. It was further discovered that MDAs that still had commitments to fulfil and did not fulfil them, could not receive their funds from donors. Non-adherence to due process seems to have put a lot of illegal funds in the hands of corrupt public servants who manage government affairs and this has oftentimes led to reckless spending at the expense of effective government service delivery.

Most public institutions' management in Nigeria engage in reckless spending and this has prevented them from releasing funds promptly for the rendition of legitimate recurrent government services. Asomba [4] reported how Professor Samuel admonished managers of tertiary institutions to adhere strictly to fiscal discipline and condemned a situation where university council members asked for first class tickets and millions of naira while on leave when their institutions cannot regularly provide for running costs. Preferring reckless spending to releasing funds for running cost is partly responsible for most fund delays in government institutions. Appropriate sanctions have been suggested for use in checking fraudulent delays in the release of funds to spending units of public institutions.

It has been reported that one way fund delays can be prevented or minimized is by sanctioning those who cause the delays. In a study carried out and reported in Absorption of Fund Brief [1] it was suggested that adherence to fund release time-table should be enforced by government and finance personnel in government agencies where release of funds is delayed should face appropriate sanctions. Monitoring and Evaluation (M\&E) and Public Expenditure Tracking Survey (PETS) were also suggested as being useful for the effective release of funds. Monitoring how the funds released reach the end-users, evaluating performance and obtaining feedback from citizens can lead to effective release and use of funds [5]. Funds can be promptly released where credit confirmation for fund release is done online. In a paper released by Dwivedi [9] it was disclosed that an e-governance activity tagged 'Online System for Credit Confirmation-Cum-Release of Funds' was introduced to facilitate the prompt release of funds to implement different government projects.

The studies reviewed so far, have disclosed the factors that determine the release of government budget implementation funds, public institutions' project implementation funds and donor agency project implementation funds. Sanctions and the use of M\&E and PETS were also suggested to facilitate the prompt release of funds to public institutions. However, those studies did not disclose the factors that determine the release of imprest funds to spending units within the public institutions of developing countries. The current study will therefore, attempt to fill this gap. 


\section{Method}

The target population for this research was 150 which consisted of academic and non-academic staff of the University of Calabar. This target population was further categorized into 88 academic staff and 62 non-academic staff of accounts, audit and budget departments of the university respectively. 126 members of this target population were accessible from which the sample size was determined using the Yaro Yamani formula as follows:

$$
n=\frac{N}{1+N(e)^{2}}
$$

Where $\mathrm{n}=$ sample size, $\mathrm{N}=$ Population and $\mathrm{e}=$ level of significance or error limit. Substituting the accessible population size of 126 and level of significance of 0.05 into the formula above, we have:

$$
\begin{aligned}
& n=\frac{126}{1+126(0.05)^{2}} \\
&=\mathrm{n}\left(1+126(0.05)^{2}\right)=126 \\
&=\mathrm{n}(1+0.315)=126 \\
&=\mathrm{n}(1.315)=126 \\
&=1.315 \mathrm{n}=126 \\
& \mathrm{n}=\frac{126}{1.315}=95.8=96 \text { Approx. }
\end{aligned}
$$

The case study approach and ex-post facto design were adopted for this study. The constraint posed by the researcher's inability to reach all the public institutions necessitated the choice of the case study approach while the inability of the researcher to manipulate the independent variables informed the use of the ex-post facto design. The six independent variables isolated for the study could not be manipulated because they had already exerted their influences on the dependent variable before the researcher got there [12]. These independent variables were: confidence in the overhead cost budget, date of approval of the overhead cost budget, imprest payment procedures, period of imprest retirement, side-lining of departmental finance officers and personal considerations. The dependent variable was: release of imprest to academic departments. A 5-point likert scale questionnaire which contained 17 structured statements was given to 96 university staff who constituted the sample. 92 respondents filled in and returned their questionnaires. 4 questionnaires were therefore, not returned. The questionnaire consisted of 7 scales representing the aforementioned independent variables and dependent variable respectively. In order to facilitate the conversion of the 5-point likert scale ordinal data to interval data, the scores of the individual likert type items from each scale, were summed up to derive composite scores for all the seven variables. These steps were taken to facilitate the application of multiple regression to the analysis of the interval data.

The relationship between the criterion and predictor variables is expressed by the following equation:

$$
\begin{gathered}
\text { ROIAC }=f(C I O C B, \text { DAOCB, IMPPP, PIMPR, SLDFO, } \\
\text { PCONS })
\end{gathered}
$$

The multiple regression model now becomes:

$$
\begin{aligned}
R O I A C=b_{0} & +b_{1} C I O C B+b_{2} D A O C B+b_{3} I M P P P \\
& +b_{4} P I M P R+b_{5} S L D F O+P C O N S+e_{i}
\end{aligned}
$$

Where,

ROIAC $=$ Release of imprest to academic departments

$\mathrm{CIOCB}=$ Confidence in the overhead cost budget

$\mathrm{DAOCB}=$ Date of approval of overhead cost budget

$\mathrm{IMPPP}=$ Imprest payment period

PIMPR $=$ Period of imprest retirement

$\mathrm{SLDFO}=$ Side-lining of departmental finance officers

PCONS $=$ Personal considerations

$b_{0}=$ the expected value (constant or intercept) of the dependent variable (ROIAC) when the independent variables equal to zero.

$b_{1}-b_{6}=$ Coefficients of the contributions of the independent variables: confidence in the overhead cost budget, date of approval of overhead cost budget, imprest payment period, period of imprest retirement, side-lining of departmental finance officers and personal considerations to the release of imprest to academic departments (ROIAC).

$$
\begin{gathered}
\mathrm{e}_{\mathrm{i}}=\text { error term } \\
\mathrm{b}_{0}, \mathrm{~b}_{1}, \mathrm{~b}_{2}, \mathrm{~b}_{3}, \mathrm{~b}_{4}, \mathrm{~b}_{5}, \mathrm{~b}_{6}, \geq 0
\end{gathered}
$$

\section{Results}

\subsection{Demographic, Response Rates and Career Status of Each Group of Sample Members}

Tables 3 and 4 show the demographic data, response rates and career status of sample members. Out of a sample of 96 members, 92 members participated and responded to the 17 likert scale items in the structured questionnaire. Males' and females' response rates were $97 \%$ and $93 \%$ respectively (see table 3). Therefore, 65 males and 27 females representing $71 \%$ and $29 \%$ respectively filled in and returned their questionnaires. The females became desirous in establishing their presence because of male dominance of the university's offices and this facilitated the easy collection of the required data. In the age-brackets of 30-40, 41-51 and 52-62 respectively, 33, 51 and 8 respondents representing 36\%, $55 \%$ and $9 \%$ respectively all filled and returned their questionnaires. Please see table 4 . All the respondents from the aforementioned age-brackets were therefore, knowledgeable and experienced. Categorization of respondents by staff cadre showed that 59 academic staff and 5 accounting staff representing $64 \%$ and $5 \%$ respectively participated in the survey while 17 audit staff and 11 budget department staff representing $19 \%$ and $12 \%$ respectively, also participated in the survey. The dominance of the academic staff was necessitated by the need to collect information directly from the population affected by the 
research problem. The participation of accounts department staff, audit department staff and budget department staff helped in assessing the validity of the responses obtained from the academic staff. All the 92 participants therefore, understood the questionnaire information very well.

\subsection{Analysis of Respondents by Number of Times Imprest Is Released to Academic Departments}

The results show the number of respondents who mentioned the number of times imprest is given to academic departments per annum in table 2. 92 academic and non-academic staff responded to the 17 Likert scale items in the structured questionnaire as follows: 4 respondents representing 4.35 percent agreed that imprest is released only once a year while 13 respondents representing 14.13 percent said imprest is released only 2 times a year. Similarly, 5 respondents representing 5.44 percent agreed that imprest is released only 4 times a year while 3 separate groups of 6 respondents each representing 6.52 percent respectively agreed that imprest is released 5 times, 6 times and 12 times a year respectively. Finally, 52 respondents representing 56.52 percent being the largest number of respondents agreed that imprest is released only 3 times a year.

\section{Regression Analysis Using Table 5}

The joint contribution of the six independent variables was moderate while the linear relationship among the variables was significant $\left(\mathrm{R}^{2}=.343, \mathrm{~F}(6,85)=7.403, \mathrm{p}<.01\right)$. The expected value (constant or intercept) of the dependent variable was positive when the independent variables equal to zero and this was also significant $\left(\beta_{0}=4.087, P<.05\right)$.

\section{Hypotheses Testing Using Regression Output Table 5}

The six null hypotheses as stated in section one were stated:

Hypothesis 1: There is no significant relationship between confidence in the overhead cost budget and release of imprest to academic departments of university of calabar. This hypothesis was not supported as there was a weak positive correlation coefficient but, this was significant $\left(\beta_{1}=.23, P<.01\right)$. The null hypothesis was therefore, rejected while the alternative was accepted.

Hypothesis 2: There is no significant relationship between date of approval of overhead cost budget and release of imprest to academic departments of university of calabar. This hypothesis was supported as there was a negligible negative correlation coefficient and this was not significant $\left(\beta_{2}=-.10, n . s\right)$. The null hypothesis was therefore, accepted while the alternative was rejected.

Hypothesis 3: There is no significant relationship between imprest payment procedures and release of imprest to academic departments of university of calabar. This hypothesis was not supported as there was a weak positive correlation coefficient and this was significant $\left(\beta_{3}=\right.$ $.30, P<.01)$. The null hypothesis was therefore, rejected while the alternative was accepted.
Hypothesis 4: There is no significant relationship between the time taken to retire imprest and release of imprest to academic departments of university of calabar. This hypothesis was not supported as there was a weak positive correlation coefficient and this was significant $\left(\beta_{4}=.31, P<.05\right)$. The null hypothesis was therefore, rejected while the alternative was accepted.

Hypothesis 5: There is no significant relationship between the side-lining of departmental finance officers and release of imprest to academic departments of university of calabar. This hypothesis was supported as there was a weak positive correlation coefficient and this was not significant $\left(\beta_{5}=.030, n . s\right)$. The null hypothesis was therefore, accepted while the alternative was rejected.

Hypothesis 6: There is no significant relationship between personal considerations and release of imprest to academic departments of university of calabar. This hypothesis was not supported as there was a moderate negative correlation coefficient and this was significant $\left(\beta_{6}=-.56, P<.01\right)$. The null hypothesis was therefore, rejected while the alternative was accepted.

\section{Discussion}

The proportion of the total variability of the dependent variable (release of imprest to academic departments) as explained by the independent variables is indicated by an $\mathrm{R}$ square of .343 or .34 approximately. (See table 5). The explanatory power of the model was significant with an Fstatistic of 7.403 at the alpha level of .01(i.e. .000). The model is therefore, highly significant but, has a low explanatory power and this therefore, justifies the analysis of each of the following hypotheses using the regression output on table 5:

\section{Hypothesis 1}

There is a positive relationship between confidence in the overhead cost budget and release of imprest to academic departments of university of calabar. But, this is weak and it is significant. $\left(\beta_{1}=.23, P<.01\right)$. What this means for the unstandardized coefficient of .229 is that if the level of confidence in the overhead cost budget increases by 1 unit, the frequency of release of imprest to academic departments will increase by only .229 , holding the other variables constant. For the standardized coefficient of .276, it means that if the level of confidence in the overhead cost budget increases by 1 standard deviation, the frequency of release of imprest to academic departments will increase by .276 standard deviation holding the other variables constant. At a t-test statistic of 2.844, this positive relationship was significant at the alpha level of .01 (i.e. .006). This positive relationship is significantly not strong enough to result in effective release of imprest. These negligible confidence coefficients of .229 and .276 suggest that confidence in the overhead cost budget is lacking even though it can be used to predict the rate at which imprest can be effectively 
released to academic departments. This finding is consistent with the works of Obadan [14] Uzochukwu, Chukwuogo and Onwujekwe [20] and Nzotta [13] where lack of confidence in the budgets of public sector organizations was discovered as being responsible for the epileptic release of funds meant for the implementation of government projects and other recurrent activities.

\section{Hypothesis 2}

There is a negative relationship between the date of approval of overhead cost budget and release of imprest to academic departments of university of calabar. This relationship is negligible and is not significant $\left(\beta_{2}=\right.$ $-.10, n . s)$. What this means for the unstandardized coefficient of -.104 is that if the date of approval of overhead cost budget is increased or extended by 1 day, the frequency of release of imprest to academic departments will decrease by -.104 holding the other variables constant. For the standardized coefficient of -.092 , it means that if the date of approval of overhead cost budget is increased or extended by 1 standard deviation, the frequency of release of imprest to academic departments will decrease by -.092 standard deviation holding the other variables constant. At a t-test statistic of -1.006 , this negative relationship was not significant at the alpha level of .05 (i.e. .317). Date of approval of overhead cost budget was not significant and this suggest that it does not have any predictive ability i.e the frequency of release of imprest to academic departments is not sensitive to changes in the date of approval of the overhead cost budget. Late approval of overhead cost budget was therefore, not responsible for the delay in the release of imprest to academic departments of university of calabar. This finding is not consistent with the works of Obadan [14] which attributed the delay in the release of budget implementation funds to the late passages of 2005 and 2006 capital budgets of Nigeria. It is also not consistent with the finding of Absorption of Fund Brief [1] that late release of funds to the energy sector of Kampala was due to delays in the approval of warrants. The contribution of the current study to the extant literature is that even though late budget approval and late release of warrant had strong association with the late release of government funds, they have negligible or no association with the release of imprest funds to spending units in public institutions of developing countries. We can however, further verify this inconsistency by extending the current research to private institutions in Nigeria.

\section{Hypothesis 3}

There is a positive relationship between imprest payment procedures and release of imprest to academic departments of university of calabar. This relationship is weak and it is significant. $\left(\beta_{3}=.30, P<.01\right)$. What this means for the unstandardized coefficient of .298 is that an increase in imprest payment procedures by 1 unit, will lead to an increase in the frequency of delays in the release of imprest to academic departments by .298 times, holding the other variables constant. For the standardized coefficient of .319, it means that an increase in imprest payment procedures by 1 standard deviation, will lead to an increase in the frequency of delays in the release of imprest to academic departments by .319 standard deviation, holding the other variables constant. At a t-test statistic of 3.124 , this positive relationship was significant at the alpha level of .01 (i.e. .002). Imprest payment procedures was significant suggesting that it has a predictive ability i.e. the rate at which imprest is released to academic departments is sensitive to imprest payment procedures. Therefore, cumbersome imprest payment procedures was responsible for the delay in the release of imprest funds to spending units of public institutions. This discovery is consistent with the studies conducted by Keng'ara [11] Dwivedi [9] Basu and Sharma [5] and SEND-Ghana, 2013 as cited in Akorli [3]) who all attributed the delay in the release of funds to the cumbersomeness of procedures.

\section{Hypothesis 4}

There is a positive relationship between the time taken to retire imprest and release of imprest to academic departments of university of calabar. This relationship is weak and it is significant. $\left(\beta_{4}=.31, P<.05\right)$. What this means for the unstandardized coefficient of .307 is that if the period taken to retire imprest is extended or increased by 1 day, the frequency of the delay in releasing imprest to academic departments will increase by .307 times, holding the other variables constant. For the standardized coefficient of .209 , it means that if the time taken to retire imprest is increased by 1 standard deviation, the frequency of the delay in releasing imprest to academic departments will increase by 209 standard deviation, holding the other variables constant. At a t-test statistic of 2.194 , this positive relationship was significant at the alpha level of .05 (i.e. .031). Period of imprest retirement was significant suggesting that it has a predictive ability i.e. the rate at which imprest is released to academic departments is sensitive to period of imprest retirement. Therefore, the longer the period of retirement the longer the time taken to release imprest to academic departments of university of calabar. Non-compliance with due process by most of the spending units was therefore, one of the reasons why public institutions' management could not release imprest funds to spending units as at when due. This finding is consistent with the findings of Absorption of Fund Brief [1] Steffensen et al [18] Rauf [17] and Quality DADP Plans [15] who all attributed the delay in the release of funds to failure of fund recipients to adhere to due process.

\section{Hypothesis 5}

There is a positive relationship between the side-lining of departmental finance officers and release of imprest to academic departments of university of calabar. This relationship is negligible and almost zero and it is not significant at a t-test statistic of .289 with an alpha level of above $.05(.773)\left(\beta_{5}=. .03, n . s\right)$. What this means for the 
unstandardized coefficient of .030 and standardized coefficient of .028 is that this independent variable called side-lining of departmental finance officers does not have any predictive ability and since its coefficient is moving towards zero, this also suggests that there is no relationship between it and the release of imprest to academic departments of university of calabar. The side-lining of departmental finance officers is therefore, not one of the reasons why imprest was not released to academic departments of university of calabar as and when due. This is not consistent with the finding of Absorption of Fund Brief [1] that the limited involvement of technical officers in the agricultural and educational sectors of India was responsible for the delay in the release of project funds. The contribution of the current research to existing literature is that limited involvement of technical officers (departmental finance officers) does not have any association with the release of imprest funds to spending units of public institutions, even though it had association with the release of project funds in Kampala.

\section{Hypothesis 6}

There is a negative relationship between personal considerations and release of imprest to academic departments of university of calabar. This relationship is moderate and is highly significant $\left(\beta_{6}=-.56, P<.01\right)$. What this means for the unstandardized coefficient of -.563 is that if personal considerations increase by 1 unit, the frequency of release of imprest to academic departments will decrease by -.563 holding the other variables constant. For the standardized coefficient of-.289, it means that if personal considerations increase by 1 standard deviation, the frequency of release of imprest to academic departments will decrease by- .289 standard deviation holding the other variables constant. At a t-test statistic of -3.245 , this negative relationship was highly significant at the alpha level of .01 (i.e. .002). Personal considerations was highly significant suggesting that it hasa predictive ability i.e as personal considerations rise, the frequency of release of imprest to academic departments decreases. Personal considerations therefore, adversely affected the rate at which imprest was released to academic departments of university of calabar. This finding is consistent with the discovery made by Asomba [4] that university council members asked for first class tickets and millions of naira while on leave when their institutions cannot regularly provide for running costs. It is also consistent with the works of SEND-Ghana, (2013 as cited in Akorli [3]) where release of project funds was delayed because contractors were intentionally frustrated to make them offer bribes.

\section{Summary, Conclusion and Recommendations}

Majority of the academic departments of university of calabar did not receive their imprests 75 percent of the time. The release of imprests funds by public institutions' managements to their spending units was inefficient and ineffective because management's confidence in the spending units' overhead cost budgets was lacking and imprest payment procedures were cumbersome. Late retirement of the imprest funds and personal considerations also adversely affected the prompt release of imprest while late approval of the overhead cost budgets and non-involvement of units' finance officers were not responsible for the late release of imprest. Confidence in the overhead cost budgets of spending units, time-saving procedures and levying of appropriate sanctions against late retirement of imprest and personal considerations can make the release of imprest become more efficient and effective.

\section{Acknowledgements}

I wish to acknowledge the assistance of academic heads of departments and staff of bursary, audit and budget departments who participated in the study. I am sincerely grateful to all those who provided useful research materials. 


\section{Appendix}

Table 1. Distribution of Likert Composite Scores of the Dependent And Independent Variables by Participants

\begin{tabular}{|c|c|c|c|c|c|c|c|}
\hline \multirow{2}{*}{ Participant ID } & $Y_{1}$ & $X_{1}$ & $\mathbf{X}_{2}$ & $\mathbf{X}_{3}$ & $\mathbf{X}_{4}$ & $\mathrm{X}_{5}$ & $X_{6}$ \\
\hline & ROIAC & CIOCB & DAOCB & IMPPP & PIMPR & SLDFO & PCONS \\
\hline 1 & 10 & 12 & 6 & 12 & 8 & 8 & 3 \\
\hline 2 & 11 & 6 & 8 & 12 & 6 & 9 & 1 \\
\hline 3 & 12 & 13 & 2 & 14 & 6 & 8 & 3 \\
\hline 4 & 13 & 12 & 6 & 13 & 6 & 4 & 2 \\
\hline 5 & 10 & 8 & 8 & 14 & 8 & 8 & 4 \\
\hline 6 & 11 & 8 & 2 & 17 & 8 & 6 & 4 \\
\hline 7 & 13 & 13 & 4 & 13 & 8 & 8 & 4 \\
\hline 8 & 11 & 10 & 2 & 14 & 8 & 3 & 5 \\
\hline 9 & 11 & 12 & 6 & 13 & 6 & 4 & 2 \\
\hline 10 & 10 & 12 & 6 & 12 & 8 & 8 & 3 \\
\hline 11 & 11 & 6 & 7 & 8 & 9 & 9 & 1 \\
\hline 12 & 12 & 13 & 2 & 14 & 6 & 8 & 3 \\
\hline 13 & 13 & 12 & 6 & 13 & 6 & 4 & 2 \\
\hline 14 & 10 & 8 & 8 & 14 & 8 & 8 & 4 \\
\hline 15 & 11 & 8 & 2 & 17 & 8 & 6 & 4 \\
\hline 16 & 14 & 13 & 4 & 13 & 8 & 8 & 4 \\
\hline 17 & 11 & 10 & 2 & 14 & 8 & 3 & 5 \\
\hline 18 & 11 & 12 & 6 & 13 & 6 & 4 & 2 \\
\hline 19 & 12 & 12 & 6 & 13 & 6 & 4 & 2 \\
\hline 20 & 12 & 12 & 6 & 13 & 6 & 4 & 2 \\
\hline 21 & 12 & 6 & 3 & 16 & 7 & 10 & 3 \\
\hline 22 & 8 & 7 & 2 & 11 & 5 & 6 & 1 \\
\hline 23 & 8 & 10 & 2 & 11 & 3 & 8 & 5 \\
\hline 24 & 9 & 10 & 6 & 13 & 6 & 8 & 4 \\
\hline 25 & 8 & 11 & 6 & 13 & 7 & 8 & 5 \\
\hline 26 & 7 & 7 & 4 & 10 & 7 & 8 & 2 \\
\hline 27 & 11 & 7 & 2 & 12 & 10 & 2 & 3 \\
\hline 28 & 7 & 10 & 3 & 11 & 6 & 4 & 3 \\
\hline 29 & 7 & 12 & 4 & 17 & 8 & 10 & 2 \\
\hline 30 & 10 & 10 & 5 & 16 & 7 & 8 & 4 \\
\hline 31 & 11 & 11 & 6 & 18 & 8 & 9 & 4 \\
\hline 32 & 9 & 9 & 4 & 14 & 6 & 8 & 4 \\
\hline 33 & 11 & 11 & 5 & 11 & 8 & 8 & 4 \\
\hline 34 & 10 & 9 & 2 & 13 & 8 & 8 & 4 \\
\hline 35 & 11 & 7 & 2 & 15 & 7 & 9 & 1 \\
\hline 36 & 11 & 7 & 3 & 14 & 6 & 6 & 2 \\
\hline 37 & 10 & 13 & 5 & 14 & 8 & 5 & 2 \\
\hline 38 & 10 & 8 & 4 & 14 & 7 & 9 & 3 \\
\hline 39 & 10 & 4 & 9 & 14 & 5 & 9 & 1 \\
\hline 40 & 10 & 11 & 10 & 19 & 8 & 10 & 4 \\
\hline 41 & 13 & 7 & 2 & 13 & 9 & 9 & 1 \\
\hline 42 & 11 & 14 & 8 & 18 & 8 & 2 & 2 \\
\hline 43 & 13 & 13 & 6 & 15 & 8 & 6 & 2 \\
\hline 44 & 10 & 9 & 3 & 16 & 4 & 10 & 4 \\
\hline 45 & 13 & 10 & 4 & 15 & 9 & 8 & 3 \\
\hline 46 & 9 & 8 & 4 & 14 & 6 & 9 & 1 \\
\hline 47 & 10 & 10 & 4 & 12 & 8 & 8 & 2 \\
\hline 48 & 8 & 10 & 8 & 14 & 8 & 9 & 2 \\
\hline 49 & 7 & 5 & 3 & 6 & 4 & 4 & 2 \\
\hline 50 & 7 & 5 & 3 & 6 & 4 & 2 & 2 \\
\hline 51 & 6 & 9 & 8 & 15 & 7 & 10 & 2 \\
\hline 52 & 6 & 9 & 6 & 8 & 8 & 8 & 4 \\
\hline 53 & 7 & 10 & 4 & 16 & 7 & 5 & 4 \\
\hline 54 & 10 & 12 & 6 & 9 & 3 & 5 & 1 \\
\hline 55 & 10 & 12 & 6 & 9 & 3 & 6 & 1 \\
\hline 56 & 14 & 14 & 7 & 19 & 8 & 8 & 3 \\
\hline
\end{tabular}


Table 1. Distribution of Likert Composite Scores of the Dependent and Independent Variables by Participants Contd.

\begin{tabular}{|c|c|c|c|c|c|c|c|}
\hline Participant ID & $\mathbf{Y}_{1}$ & $\mathbf{X}_{1}$ & $\mathbf{X}_{2}$ & $\mathbf{X}_{3}$ & $\mathbf{X}_{4}$ & $\mathbf{X}_{5}$ & $X_{6}$ \\
\hline & ROIAC & CIOCB & DAOCB & IMPPP & PIMPR & SLDFO & PCONS \\
\hline 57 & 7 & 10 & 3 & 11 & 8 & 8 & 4 \\
\hline 58 & 11 & 12 & 8 & 15 & 8 & 8 & 4 \\
\hline 59 & 14 & 11 & 3 & 14 & 9 & 10 & 1 \\
\hline 60 & 12 & 8 & 6 & 15 & 6 & 10 & 5 \\
\hline 61 & 14 & 6 & 4 & 15 & 6 & 8 & 3 \\
\hline 62 & 9 & 14 & 4 & 15 & 8 & 9 & 5 \\
\hline 63 & 12 & 10 & 2 & 14 & 8 & 8 & 2 \\
\hline 64 & 4 & 5 & 6 & 13 & 4 & 6 & 4 \\
\hline 65 & 13 & 8 & 6 & 14 & 8 & 9 & 2 \\
\hline 66 & 8 & 3 & 2 & 13 & 4 & 5 & 2 \\
\hline 67 & 13 & 11 & 8 & 15 & 6 & 9 & 2 \\
\hline 68 & 10 & 11 & 6 & 15 & 6 & 9 & 2 \\
\hline 69 & 10 & 11 & 6 & 12 & 5 & 9 & 4 \\
\hline 70 & 9 & 6 & 4 & 11 & 6 & 4 & 2 \\
\hline 71 & 9 & 5 & 4 & 12 & 6 & 8 & 2 \\
\hline 72 & 13 & 11 & 5 & 14 & 6 & 6 & 3 \\
\hline 73 & 11 & 7 & 6 & 14 & 9 & 7 & 4 \\
\hline 74 & 14 & 14 & 7 & 19 & 8 & 8 & 3 \\
\hline 75 & 9 & 10 & 3 & 12 & 7 & 8 & 4 \\
\hline 76 & 13 & 12 & 8 & 14 & 8 & 8 & 4 \\
\hline 77 & 14 & 11 & 3 & 14 & 9 & 10 & 1 \\
\hline 78 & 12 & 8 & 6 & 15 & 6 & 10 & 5 \\
\hline 79 & 14 & 6 & 4 & 15 & 6 & 8 & 3 \\
\hline 80 & 9 & 14 & 4 & 14 & 8 & 9 & 5 \\
\hline 81 & 12 & 10 & 2 & 14 & 8 & 8 & 2 \\
\hline 82 & 4 & 5 & 6 & 13 & 4 & 6 & 4 \\
\hline 83 & 13 & 8 & 6 & 14 & 8 & 9 & 2 \\
\hline 84 & 8 & 3 & 2 & 13 & 4 & 5 & 2 \\
\hline 85 & 13 & 11 & 8 & 15 & 6 & 9 & 2 \\
\hline 86 & 10 & 11 & 6 & 15 & 6 & 9 & 2 \\
\hline 87 & 10 & 11 & 6 & 14 & 5 & 9 & 4 \\
\hline 88 & 9 & 6 & 4 & 9 & 6 & 4 & 2 \\
\hline 89 & 9 & 5 & 4 & 12 & 6 & 8 & 2 \\
\hline 90 & 13 & 11 & 5 & 14 & 6 & 6 & 3 \\
\hline 91 & 11 & 7 & 6 & 14 & 9 & 7 & 4 \\
\hline 92 & 14 & 12 & 2 & 17 & 5 & 9 & 2 \\
\hline
\end{tabular}

Key:

ROIAC $=$ Release of imprest to academic departments

$\mathrm{CIOCB}=$ Confidence in the overhead cost budget

$\mathrm{DAOCB}=$ Date of approval of overhead cost budget

IMPPP $=$ Imprest payment period

PIMPR $=$ Period of imprest retirement

SLDFO $=$ Side-lining of departmental finance officers

PCONS $=$ Personal considerations 
Determinants of the Release of Imprest to Units within Public Institutions of

Developing Countries: Evidence from University of Calabar, Nigeria

Table 2. Distribution of Respondents by Number of Times Imprest Is Collected Per Annum

\begin{tabular}{|c|c|c|}
\hline $\begin{array}{c}\text { No. of Times Imprest Is Collected Per } \\
\text { Annum }\end{array}$ & $\begin{array}{c}\text { Number of Respondents Who Say Imprest } \\
\text { Is Colleceted for Each No. of Times }\end{array}$ & Percentage Number of Respondents \\
\hline 1 & 4 & 4.35 \\
\hline 2 & 13 & 56.52 \\
\hline 3 & 52 & 5.44 \\
\hline 4 & 5 & 6.52 \\
\hline 5 & 6 & 6.52 \\
\hline 6 & 6 & 0 \\
\hline 7 & 0 & 0 \\
\hline 8 & 0 & 0 \\
\hline 9 & 0 & 0 \\
\hline 10 & 0 & 0 \\
\hline 11 & 0 & 6.52 \\
\hline 12 & 6 & $\mathbf{1 0 0}$ \\
\hline TOTAL & $\mathbf{9 2}$ & 0 \\
\hline
\end{tabular}

Table 3. Population, Sample and Response Rate of Each Group

\begin{tabular}{|c|c|c|c|c|}
\hline GENDER: & POPULATION & SAMPLE & RESPONSE & RESPONSE RATE \\
\hline Male & $100(67 \%)$ & 67 & 65 & $97 \%$ \\
\hline Female & $50(33 \%) \mathbf{1 0 0} \%$ & 29 & 27 & $93 \%$ \\
\hline AGE: & & & & $97 \%$ \\
\hline $30-40$ & $55(40 \%)$ & 34 & 53 & $98 \%$ \\
\hline $41-51$ & $75(50 \%)$ & 52 & 81 & $80 \%$ \\
\hline $52-62$ & $20(10 \%) \mathbf{1 0 0} \%$ & 10 & 59 & $98 \%$ \\
\hline STAFF CADRE: & & & 5 & $83 \%$ \\
\hline Academic & $88(59 \%)$ & 60 & 17 & $94 \%$ \\
\hline Accounts & $10(7 \%)$ & 6 & 11 & $92 \%$ \\
\hline Audit & $29(19 \%)$ & 12 & $\mathbf{9 2}$ & \\
\hline Budget & $23(15 \%) \mathbf{1 0 0} \%$ & $\mathbf{1 5 0}$ & & \\
\hline TOTAL: & & & & \\
\hline
\end{tabular}

Table 4. Biographical Data Of Respondents

\begin{tabular}{|c|c|c|}
\hline GENDER: & FREQUENCY & PERCENT \\
\hline Male & 65 & $21 \%$ \\
\hline Female & 27 & $36 \%$ \\
\hline AGE: & & $55 \%$ \\
\hline $30-40$ & 33 & $9 \%$ \\
\hline $41-51$ & 51 & \\
\hline $52-62$ & 8 & $64 \%$ \\
\hline STAFF CADRE: & & $5 \%$ \\
\hline Academic & 59 & $19 \%$ \\
\hline Accounts & 5 & $12 \%$ \\
\hline Audit & 17 & \\
\hline Budget & 11 & \\
\hline
\end{tabular}


Table 5. Regression

\begin{tabular}{|c|c|c|c|c|c|c|c|}
\hline \multicolumn{8}{|c|}{ Variables Entered/Removed $^{\text {b }}$} \\
\hline \multicolumn{2}{|c|}{ Model } & \multicolumn{2}{|c|}{ Variables Entered } & \multicolumn{2}{|c|}{ Variables Removed } & \multicolumn{2}{|c|}{ Method } \\
\hline \multicolumn{2}{|c|}{1} & \multicolumn{2}{|c|}{$\begin{array}{l}\text { Personal considerations, Date of } \\
\text { approval of overhead cost budget, } \\
\text { Period of imprest retirement, } \\
\text { Side-lining of departmental finance } \\
\text { officers, Confidence in the } \\
\text { overhead cost budget, Imprest } \\
\text { payment procedures }^{\mathrm{a}}\end{array}$} & . & & \multicolumn{2}{|c|}{ Enter } \\
\hline \multicolumn{8}{|c|}{ a. All requested variables entered. } \\
\hline \multicolumn{8}{|c|}{ b. Dependent Variable: Release of imprest to academic depts. } \\
\hline \multicolumn{8}{|c|}{ Model Summary } \\
\hline \multicolumn{2}{|c|}{ Model } & \multicolumn{2}{|c|}{$\mathrm{R}$} & \multicolumn{2}{|c|}{ R Square } & $\begin{array}{l}\text { Adjusted R } \\
\text { Square }\end{array}$ & $\begin{array}{l}\text { Std. Error of the } \\
\text { Estimate }\end{array}$ \\
\hline \multicolumn{2}{|c|}{1} & \multicolumn{2}{|c|}{$.586^{\mathrm{a}}$} & \multicolumn{2}{|c|}{.343} & .297 & 1.924 \\
\hline \multicolumn{8}{|c|}{$\begin{array}{l}\text { a. Predictors: (Constant), Personal considerations, Date of approval of overhead cost budget, Period of imprest retirement, Side-lining of } \\
\text { departmental finance officers, Confidence in the overhead cost budget, Imprest payment procedures }\end{array}$} \\
\hline \multicolumn{8}{|c|}{ ANOVA $^{\mathrm{b}}$} \\
\hline \multicolumn{2}{|l|}{ Model } & Sum of Squares & Df & \multicolumn{2}{|c|}{ Mean Square } & $\mathrm{F}$ & Sig. \\
\hline \multirow{3}{*}{1} & Regression & 164.366 & 6 & \multicolumn{2}{|c|}{27.394} & 7.403 & $.000^{\mathrm{a}}$ \\
\hline & Residual & 314.536 & 85 & \multicolumn{2}{|c|}{3.700} & & \\
\hline & Total & 478.902 & 91 & & & & \\
\hline \multicolumn{8}{|c|}{$\begin{array}{l}\text { a. Predictors: (Constant), Personal considerations, Date of approval of overhead cost budget, Period of imprest retirement, Side-lining of } \\
\text { departmental finance officers, Confidence in the overhead cost budget, Imprest payment procedures }\end{array}$} \\
\hline \multicolumn{8}{|c|}{ b. Dependent Variable: Release of imprest to academic depts. } \\
\hline \multicolumn{8}{|c|}{ Coefficients $^{\mathrm{a}}$} \\
\hline \multirow{2}{*}{\multicolumn{2}{|c|}{ Model }} & $\begin{array}{l}\text { Unstandardized } \\
\text { Coefficients }\end{array}$ & $\begin{array}{l}\text { Standardized } \\
\text { Coefficients }\end{array}$ & $\begin{array}{l}\text { Unstandardized } \\
\text { Coefficients }\end{array}$ & \multirow[t]{2}{*}{$\mathrm{T}$} & \multirow{2}{*}{\multicolumn{2}{|c|}{ Sig. }} \\
\hline & & $\mathrm{B}$ & Std. Error & $\mathrm{B}$ & & & \\
\hline \multirow{7}{*}{1} & (Constant) & 4.087 & 1.342 & & 3.045 & & 03 \\
\hline & $\begin{array}{l}\text { Confidence in } \\
\text { the overhead } \\
\text { cost budget }\end{array}$ & .229 & .081 & .276 & 2.844 & & 06 \\
\hline & $\begin{array}{c}\text { Date of } \\
\text { approval of } \\
\text { overhead cost } \\
\text { budget }\end{array}$ & -.104 & .103 & -.092 & -1.006 & & 17 \\
\hline & $\begin{array}{c}\text { Imprest } \\
\text { payment } \\
\text { procedures }\end{array}$ & .298 & .095 & .319 & 3.124 & & 02 \\
\hline & $\begin{array}{c}\text { Period of } \\
\text { imprest } \\
\text { retirement }\end{array}$ & .307 & .140 & .209 & 2.194 & & 31 \\
\hline & $\begin{array}{c}\text { Side-lining of } \\
\text { departmental } \\
\text { finance officers }\end{array}$ & .030 & .103 & .028 & .289 & & 73 \\
\hline & $\begin{array}{c}\text { Personal } \\
\text { considerations }\end{array}$ & -.563 & .173 & -.296 & -3.245 & & 02 \\
\hline
\end{tabular}

[2] Adeshoba, J. A. Internal audit procedures and operations challenges and initiatives. 2011; Available from http://www.bulletin.oqufe.edu.ng/download/11-internal-audi t-procedures-and-operations-challenges.

\section{REFERENCES}

[1] Absorption of Fund Brief. Low absorption of funds in public programmes during July-Dec 2012: What are the key reasons? 2013; Ministry of Finance, Planning and Economic Development, Kampala.

[3] Akorli, C. The cold facts of delays in common fund disbursement. Ghana Business News (GBN). 2015; Available from http://www.ghanabusinessnews.com/2015/04/25/the-co ld-facts-of-delays-in-common-fund-disbu. 
[4] Asomba, I. Don calls for total deregulation of tertiary education. Vanguard Newspaper.2012 December 27; Available from http://www.vanguardngr.com/2012/12/don-c alls-for-total-deregulation-of-tertiary-education/.

[5] Basu A. \& Sharma V. Final report on public financial management system. 2010; European Union State Partnership Programme, Chattisgarh.

[6] Cantoria, C. S. Coming up with policies and procedures for handling petty cash funds. 2011; Available from http://www.brighthub.com/office/finance/articles/119077.asp $\mathrm{x}$.

[7] Danka, U. Petty cash disbursements. Team Mate Ecosystem for Audit. 2012; Available fromhttps://iaonline.theiia.org/pet ty-cash-disbursements.

[8] Dankwambo, I. H. Cash management: The flow of funds from warrants release to cash-backing. 2009; Workshop on budget implementation, monitoring and evaluation organized by the budget office of the federation in collaboration with the World Bank, Abuja, Nigeria.

[9] Dwivedi, H. K. Introduction of online system for credit confirmation and release of funds. 2014; Government of West Bengal Finance Department, Budget Branch.

[10] Inyang, W. S. The impact of overhead cost budgeting on the annual imprest expenditures of State Ministries, Departments and Agencies (MDAs): A study from Cross River State, Nigeria. International Business Research 2013; 6(6): 129-142. Doi: 10.5539/ibr.v6n6p129.

[11] Keng'ara, R. Effect of funds disbursement procedures on implementation of donor projects in Homabay County, Kenya. Universal Journal of Accounting and Finance 2014; 2(1): 9-23. DOI: 10.13189/ujaf.2014.020102.

[12] Kerlinger, F. N. Foundations of behavioural research. (3rd ed.), Orlando, FL: Harcourt Brace \& Company. 1986.

[13] Nzotta, B. C. Power and authority in the administration of College of Education Libraries in Nigeria. Annals of Library Science and Documentation.1987; 34(3): 77-89.

[14] Obadan, M. I. 2008 Federal capital budget implementation: Factors affecting performance. [Date unknown]. Available from www.budgetoffice.gov.ng/original.html.
[15] Quality DADP Quality DADP plans and timely funds release. [date unknown]. Vailable from http://ansaf.or.tz/uploads/Far mers\%20Magazine\%20- \%20ANSAF\%20FINAL\%20OUT. pdf.

[16] Ragusa, J. What is the nature of the imprest system? 2015; Available fromhttp://www.answers.com/Q/what-is-the-natur e-of-the-imprest-system.

[17] Rauf, A. K-P Govt responsible for delay in release of PSDP funds from Centre. Office of the New York State Comptroller. 2014; Available fromhttp://tribune.com.pk/story/659641/k-p -govt-responsible-for-delay-in-release-of-psdp-funds-from-c entre/.

[18] Steffensen, J., Mathur R., Singh, S. K. \& Moulik, S. G. First independent review mission for backward regions grant fund - State Report. 2009;

[19] Usabor, E. E. School imprest system and administrative effectiveness of secondary school principals in Uyo Senatorial District of Akwa Ibom State, Nigeria. Journal of Research in Education and Society 2014; 5(3): 20-24.

[20] Uzochukwu, B. S. C., Chukwuogo, O. \& Onwujekwe, O. E. Financing immunization for results in Nigeria: Who funds, who disburses, who utilizes, who accounts? Financing bottlenecks and accountability challenges. African Journal of Health Economics. 2014; 8: 1- 9.

[21] Wilkinson, J. Imprest account in Wiki CFO. 2013; Available from http://strategiccfo.com/wikicfo/imprest-account/.

[22] Owojori, A. A. \& Asaolu, T. O. Critical evaluation of personnel management problems in the Nigerian school system. Int. J. Edu Sci. 2010; 2(1): 1-11.

[23] Okafor, R. G. Accounting education in Nigerian Universities: Challenges and prospects. Journal of Economics and Sustainable Development. 2012; 3(14).

[24] Kikwasi, G. J. Causes and effects of delays and disruptions in construction projects in Tanzania. Australasian Journal of Construction Economics and Building Conference Series. 2012; 1(2): 52-59.

[25] Oyekanmi, R. L. Universities NEEDS assessment report presentation to NEC November 2012; Available from http://www.nigerianmuse.com/20130924094415zg/sections/ general-articles/universiti... 